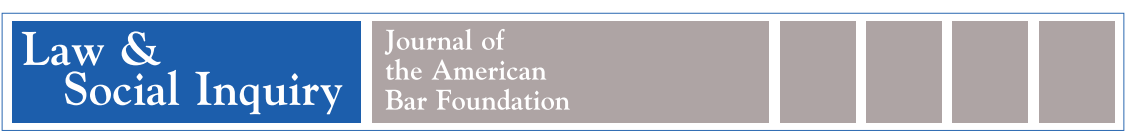

Law Eु Social Inquiry

Volume 44, Issue 1, 102-135, February 2019

\title{
Slavery and Just Compensation in American Constitutionalism
}

\author{
Stephan Stohler
}

\begin{abstract}
The existence of compensation clauses, guaranteeing compensation when governments took private property, in antebellum state constitutions varied considerably across states and over time. Existing explanations struggle to account for such variation. I argue that slavery had an important, though varied, influence, depending on the changing strategic behavior of proslavery constitutional drafters. Proslavery delegates opposed compensation when they expected to control political decision making, but supported compensation when uncertain. This argument identifies another way that slavery impacted US constitutional development, and further suggests that American rights development resembles the experiences of other countries where elite interests were threatened.
\end{abstract}

\section{INTRODUCTION}

Proslavery delegates who met in Lecompton, Kansas in 1857 drafted what is perhaps the most notorious constitution in US history. The document clearly established slavery in the territory, exacerbating the concerns of antislavery forces throughout the country and ultimately dividing the Democratic Party in the run-up to the 1860 election (Graber 2006, 40). Proslavery delegates had turned to constitutionalism in this instance because they feared abolition once Kansas joined the Union. Abolition was a distinct possibility. There is some evidence that antislavery voters already constituted a majority in the territory (Etchenson 2004, 2), but even if precise evidence was not available, it was unmistakably clear that Free Soilers from other states had entered Kansas in large numbers to vote illegally against slavery's establishment (Etchenson 2008, 160). Proslavery delegates, therefore, sought to protect slave owners from future, democratically elected governments by including, among other things, strong assurances that slave owners would receive financial compensation in the event of abolition (Kansas [Lecompton] Constitution of 1857 [Failed], Art. VII, § 2).

Antislavery delegates convened the following year in Leavenworth to draft a rival alternative. The Leavenworth Constitution contained few protections for slave owners and no explicit provision guaranteeing financial compensation for slavery, even though the constitution offered other property owners some protections

Stephan Stohler is an Assistant Professor of Political Science at SUNY, University at Albany. The author thanks Greg Ablavsky, David Bateman, Matt Ingram, Bruce Miroff, Anne Norton, Julie Novkov, Gideon Parchomovsky, Christopher Serkin, Rogers Smith, Emily Thorson, Tim Weaver, Robinson Woodward-Burns, Emily Zackin, members of the Politics and History Workshop at the University at Albany, and the anonymous reviewers for their helpful comments and suggestions. Please direct all comments to sstohler@albany.edu. 
against internal improvements (Kansas [Leavenworth] Constitution of 1858 [Failed], Art. I, § 19, Art. XV, §1).

Ultimately, Congress did not accept either the Lecompton or the Leavenworth constitution. The two documents are instructive nonetheless because they provide clues about the relationship between slavery and just compensation in US constitutionalism. Drawing on a newly assembled data set of eighty-one antebellum state constitutions and their drafting conventions (1776-1860), I demonstrate that slavery was simultaneously an inhibitor and promoter of just compensation in American constitutionalism, depending on the strategic decisions of proslavery delegates at state drafting conventions. Proslavery delegates were ambivalent about compensation clauses because, although they secured value, these provisions implicitly condoned regulation and perhaps even facilitated takings. If slave owners expected to control political decision making, they would generally oppose compensation clauses, which might encourage political opponents to seek compensated emancipation. Evidence from state constitutions demonstrates that these documents had relatively low compensation adoption rates. However, if slave owners believed they would not retain firm control over government, like those at Lecompton, then they supported compensation clauses either to secure fair value or to raise the costs of emancipation, often to a prohibitive level. These constitutions had relatively high compensation adoption rates. When proslavery delegates were absent from conventions, like those excluded at Leavenworth, they were in no position to influence the adoption of compensation clauses. Other property issues were undoubtedly present at conventions where proslavery delegates participated, but at conventions such as Leavenworth they proved decisive. These constitutions contained compensation clauses at moderate rates. Case studies of various conventions further support proslavery delegates' varied commitment to just compensation depending on slavery's or their own political futures.

This explanation about the origins of just compensation in US constitutions differs from existing accounts. Many claim that compensation clauses, like the one found in the Fifth Amendment to the US Constitution, ${ }^{1}$ find their origins in debates about internal improvements, but compensation clauses were notably absent from constitutions in many places that spent a great deal on internal improvements, especially in South Atlantic states. Nor do accounts, which stress ideological shifts or diffusion of constitutional drafting practices, capture the regional and temporal variation in compensation clauses found in state constitutional documents.

We no longer associate constitutional compensation guarantees with slavery because of the reconstruction of the US Constitution following the Civil War. The Fourteenth Amendment put a decisive end to the practice of compensated emancipation, holding that "neither the United States nor any State shall assume or pay ... for the loss or emancipation of any slave" (US Constitution, Amendment XIV, $\S 4$ ), and yet we should nonetheless care about this lost history for several reasons. First, this argument contributes to a growing literature that identifies the impact of slavery and illiberal motives on American constitutional development (Smith 1993,

1. US Constitution, Amendment V ("nor shall private property be taken for public use, without just compensation"). 
1997; King and Smith 2005; Einhorn 2006; Herron 2015). Second and relatedly, slavery's influence on the adoption of compensation clauses suggests that the liberal rights tradition is in part the product of short-term, often illiberal, impulses by political elites seeking to preserve their interests in reaction to the emancipatory potential of democratization. American constitutional development, on this view, is not so different from rights development elsewhere (Hirschl 2004), even though such similarities often have not been acknowledged.

\section{POLITICAL INFLUENCES ON COMPENSATION CLAUSES}

Many property issues raised political and constitutional concerns in antebellum US politics (Nedelsky 1990; Ackerman 1991), but slavery was special for several reasons. First, investments in slavery were massive. They constituted the single largest economic investment in antebellum America (Piketty 2014, 158-62). Second, emancipation created special problems for slave owners and in ways that were distinct from other types of property. In the aftermath of emancipation, elites would seemingly either have to pay for the removal of freed slaves under some form of colonization scheme (Ford 2011, 370) or face a new political environment in which freed slaves remained and, potentially, tried to claim slave owners' other property. Such redistributive concerns were particularly acute in the South's slave societies, which were more unequal, had the most concentrated wealth, and had the richest elites (Soltow 1989). Under these circumstances, wealthy slave-owning elites were sensitive to the risks of expropriation that came with democratization. Third, such concerns were only exacerbated by a small but growing proportion of the national population that was uncomfortable with the legal protection of human property. To be sure, these slave societies also witnessed debates about land expropriation (McDonnell 2006), but the dynamics of large-scale emancipation were largely missing in more egalitarian states such as Vermont, New Hampshire, or Pennsylvania (Soltow 1989), where property owners' shared concerns about land reform and slavery were addressed through gradual emancipation schemes (Litwack 1961). The interests of slave owners, therefore, were not necessarily the same as those of other property owners. Under some circumstances, those interests overlapped, but under other circumstances, they diverged.

Slave owners and constitutional drafters attentive to their interests therefore had strong motives to devise rules to protect their investments, often through compensation guarantees. Some circumstantial evidence suggests that the Fifth Amendment's drafter, James Madison, was attentive to precisely such concerns about slavery. Madison remarked many years after drafting the Bill of Rights that "whatever may be the intrinsic character of that description of [slavery], it is one known to the constitution, and, as such could not be constitutionally taken away without just compensation" (Madison [1819] 1900). President Abraham Lincoln had something similar in mind when he offered to pay for all slaves in a desperate appeal to the border states, especially Kentucky, to remain in the Union (Lincoln 1862; Fladeland 1976, 185). However, few are willing to attribute similar motives 


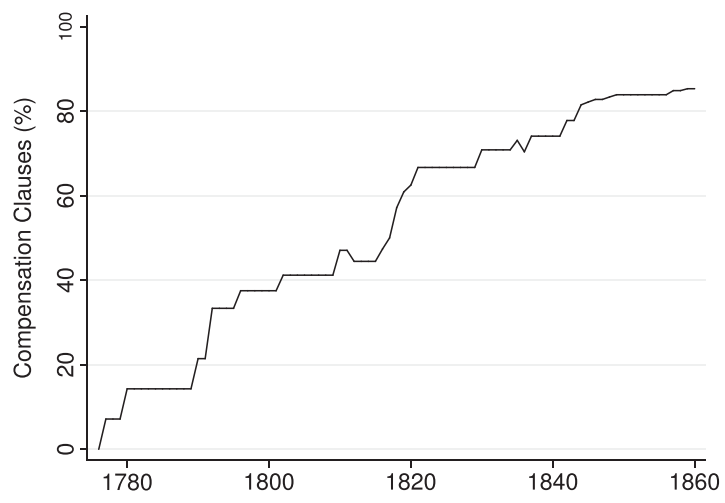

FIGURE 1.

Compensation Clauses in Antebellum Constitutions (1776-1860)

to antebellum constitutional drafters, despite the temporal proliferation of such provisions as slavery became more contested during the antebellum period (Figure 1). ${ }^{2}$

Alternative, though not necessarily inconsistent, theories have shaped our understanding of the origins of just compensation in US constitutionalism. Foremost among these is the claim that compensation clauses were driven by internal improvements and by public works projects to improve transportation infrastructure (Hurst 1956; Horwitz 1977; Ely 2008, 5). The pro-business Whig Party perhaps advocated such projects most aggressively during the antebellum period, though the party hardly exercised a monopoly on the policy (Goodrich 1960; Holt 1977). On this view, compensation clauses constrained governments to ensure that property owners were protected from total losses. However, compensation clauses also gave governments license to confiscate property if they paid.

The argument about internal improvements is not inconsistent with the influence of slavery. Some drafters, like those at the Lecompton convention, simultaneously supported compensation clauses to regulate slavery and offer protection from corporations that might expropriate other types of property, ${ }^{3}$ but in other places, such as Virginia, proslavery delegates expressed concern that western representatives would tax eastern slave owners to pursue infrastructure projects that would effectively abolish slavery (Freehling 1982, Ch. 5). Indeed, South Atlantic states like Virginia benefited from the second highest level of improvement funding, receiving 25 percent of federal appropriations between 1800 and 1860 (Malone 1998, 24), but until Virginia's convention of 1830 , these states did not adopt compensation clauses of any kind, and many would resist until after the Civil War (Figure 2). ${ }^{4}$

2. Figures 1 and 2 contain data only from adopted state constitutions.

3. Consider Kansas [Lecompton] Constitution of 1857 (Failed), Art. XII, § 2.

4. The regional and divisional designations are adopted from the US Census. The New England region consists of Connecticut, Maine, Massachusetts, New Hampshire, Rhode Island, and Vermont; Middle Atlantic: New Jersey, New York, and Pennsylvania; East North Central: Indiana, Illinois, Michigan, Ohio, and Wisconsin; West North Central: Iowa, Kansas, Minnesota, Missouri; South Atlantic: Delaware, Florida, Georgia, Maryland, North Carolina, South Carolina, Virginia; East South Central: Alabama, Kentucky, Mississippi, Tennessee; West South Central: Arkansas, Louisiana, Texas; Pacific: California, Oregon. 

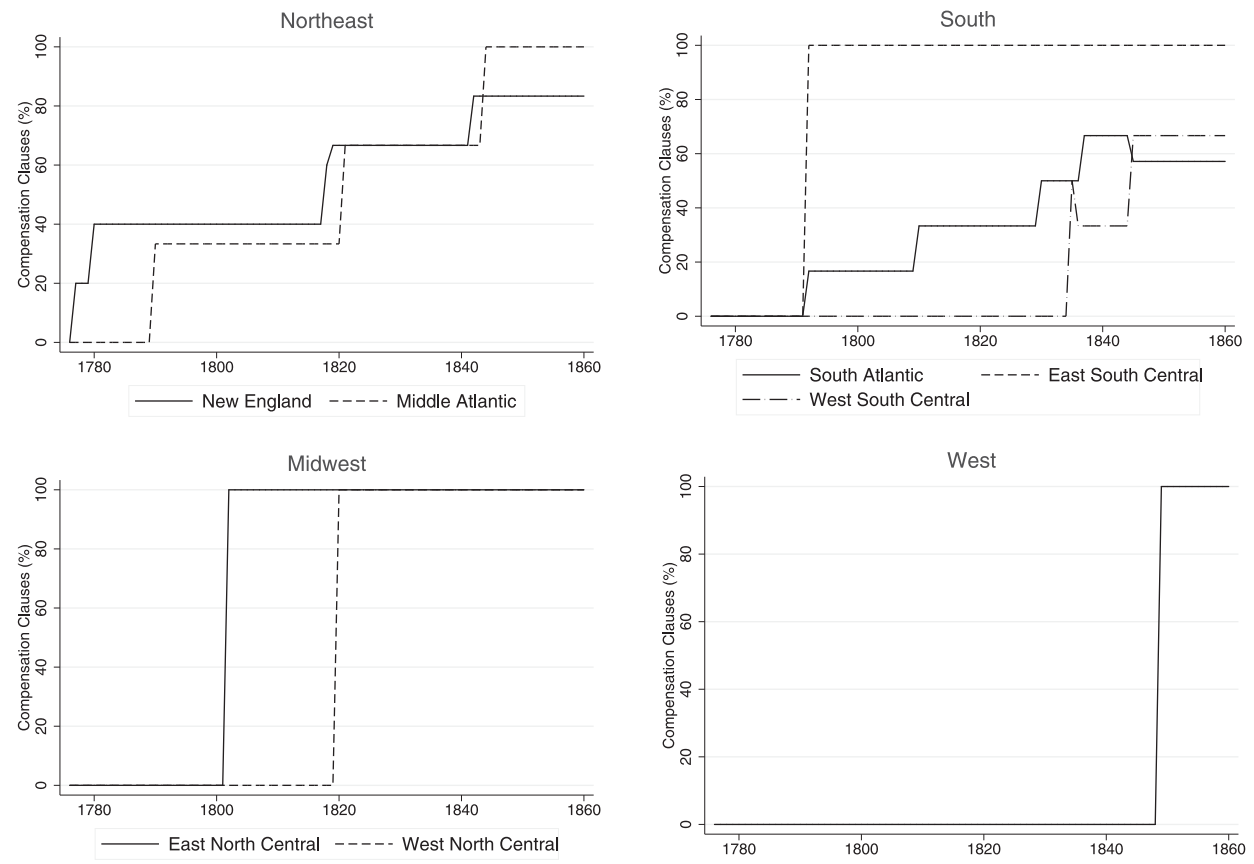

FIGURE 2.

Compensation Clauses by Region and Division (1776-1860)

There were undoubtedly a variety of motives supporting compensation clauses at any antebellum constitutional convention. The precise membership of a compensation clause coalition, however, is difficult to determine. Bills of rights were almost always drafted in special committees at antebellum state drafting conventions. These committees rarely kept records of drafting debates. In some circumstances, conventions held final votes on bills of rights, but they were up-or-down votes on the entirety of the bill of rights. Therefore, it is impossible to determine from such votes alone whether a particular vote could be attributed to the existence or absence of a compensation clause. The argument advanced here simply suggests that conventions in which proslavery delegates felt politically vulnerable would adopt compensation clauses at higher rates than in places where they exercised no influence, perhaps because they found willing coalition partners who pursued different goals through similar means.

Alternatively, some have suggested that compensation clauses followed a certain ideological shift after the Articles of Confederation (1777). In his leading article, William Treanor (1995) suggests that the Fifth Amendment's compensation clause emerged after an intellectual shift from republicanism to Lockean or liberal ideas. That ideological transition, Treanor argues, had important implications for private property. Older, republican notions of governance and citizenship, Treanor finds, required that private property owners defer more readily to public authority. Lockean ideals, on the other hand, did not impose similar requirements. Drafters, 
such as Madison, were therefore less tolerant of public efforts to interfere with private property.

Lockean ideals undoubtedly shaped antebellum US politics. Whether such ideals can be neatly disassociated from the politics of slavery, as Treanor (1995, 851-54) himself notes, is another matter. Slave owners often defended their property interests by drawing on Lockean ideals (Hartz 1955, 154), or at least appealed to Lockean ideals alongside ascriptive arguments to support legal and constitutional positions throughout the antebellum period (Smith 1997). In other words, these various intellectual strands were present simultaneously and throughout the antebellum period. However, many state constitutions, drafted while the First Congress debated the Bill of Rights or shortly thereafter, did not contain similar compensation guarantees, suggesting that the relative influence of various constitutional ideals alone did not drive the varied proliferation of compensation clauses (Figure 2).

Nor can the varied proliferation of compensation clauses be explained by passive diffusion arguments. The variation in compensation clauses is simply too great to support a conclusion that delegates simply copied bills of rights from existing constitutions (Table 1). Rather, if drafters borrowed from other constitutions, they did so selectively and strategically. Secondary analysis supports this conclusion. Alabama's drafters, for example, strategically borrowed from Kentucky, Georgia, and Mississippi (McMillan 1951, 88; Winkle 2014). There is no evidence that Alabama's drafters looked to Vermont or Massachusetts for inspiration about how they should manage slavery.

Of course, slave owners' preferences were not the only important factor motivating just compensation, but their decisions to support compensation were often decisive. Those decisions turned on a set of strategic calculations about their own or slavery's future and often caused them to embrace compensation clauses as an alternative to decisive control over government decision making.

\section{COMPENSATION AS A HEGEMONIC PRESERVATION STRATEGY}

Proslavery delegates' strategic calculations follow from hegemonic preservation theory. This class of arguments asserts that political elites turn to courts and constitutionalism as part of a strategic assessment of future political power (Ginsburg 2003; Hirschl 2004; Finkel 2008; Zackin 2013). Applied to slave owners during the antebellum period, when proslavery delegates could entrench slavery's power in elected institutions, rights protections provided a second-best alternative that they often sought to avoid. Although compensation clauses might have protected slave owners from a total loss or otherwise discouraged abolition by substantially increasing its political and financial costs, these provisions implicitly condoned-and perhaps even facilitated-abolition. The US Congress pursued this policy in Washington, DC when it enacted the District of Columbia Compensated Emancipation Act. ${ }^{5}$ The decision to abolish slavery in Washington, DC was undoubtedly controversial. However, it was constitutionally permissible because it complied with

5. An Act for the Release of Certain Persons Held to Service or Labor in the District of Columbia (District of Columbia Compensated Emancipation Act), 12 Stat. 376 (1862). 
TABLE 1.

Textual Variation in Compensation Clauses

\begin{tabular}{|c|c|c|}
\hline Year & Constitution & Clause \\
\hline 1777 & Vermont & $\begin{array}{l}\text { "That private Property ought to be subservient to public Uses } \\
\text { when necessity requires it; nevertheless, whenever any partic- } \\
\text { ular man's Property is taken for the Use of the public, the } \\
\text { Owner ought to receive an equivalent in Money." }\end{array}$ \\
\hline 1780 & Massachusetts & $\begin{array}{l}\text { "And whenever the public exigencies require, that the property } \\
\text { of any individual should be appropriated to public uses, he } \\
\text { shall receive a reasonable compensation therefor." }\end{array}$ \\
\hline 1790 & United States & $\begin{array}{l}\text { "[N]or shall private property be taken for public use, without } \\
\text { just compensation." }\end{array}$ \\
\hline 1796 & Tennessee & $\begin{array}{l}\text { "That no man's particular Services shall be demanded or prop- } \\
\text { erty taken or applied to public use, without the Consent of } \\
\text { his Representatives or without Just compensation being made } \\
\text { therefor." }\end{array}$ \\
\hline 1810 & West Florida & $\begin{array}{l}\text { "[N]or shall any man's property be taken or applied to public } \\
\text { use without just compensation being made to him therefor." }\end{array}$ \\
\hline 1820 & New York & $\begin{array}{l}\text { "Private property shall not be taken for public use without just } \\
\text { compensation; but land may be taken for public highways as } \\
\text { heretofore until the legislature shall direct compensation to } \\
\text { be made." }\end{array}$ \\
\hline 1837 & Maryland & $\begin{array}{l}\text { "And be it enacted, That the relation of master and slave, in } \\
\text { this State, shall not be abolished unless a bill so to abolish } \\
\text { the same, shall be passed by a unanimous vote of the mem- } \\
\text { bers of each branch of the General Assembly, and shall be } \\
\text { published at least three months before a new election of dele- } \\
\text { gates, and shall be confirmed by a unanimous vote of the } \\
\text { members of each branch of the General Assembly, at the } \\
\text { next regular constitutional session after such new election, } \\
\text { nor then, without full compensation to the master for the } \\
\text { property of which he shall be thereby deprived." }\end{array}$ \\
\hline 1844 & New Jersey & $\begin{array}{l}\text { "Private property shall not be taken for public use without just } \\
\text { compensation; but land may be taken for public highways as } \\
\text { heretofore until the legislature shall direct compensation to } \\
\text { be made." }\end{array}$ \\
\hline
\end{tabular}

the Fifth Amendment's compensation clause. It was politically feasible, perhaps, only because compensation shielded slave owners from a total loss (Provine 2009).

Consistent with this theory, proslavery constitutional drafters would have preferred to avoid such risks by retaining for themselves the ability to control future political decisions. They could retain that authority, perhaps, by manipulating the rules for democratic representation. Proslavery delegates in many southern states, for example, often required elected representatives to own large estates or a certain number of slaves. ${ }^{6}$ Such provisions ensured that political representatives retained a

6. South Carolina Constitution of 1790, Art. I, § 6 . 
financial stake in the slave economy. ${ }^{7}$ With secure control of a state's governing institutions, proslavery delegates had little use for compensation clauses and the attendant risks they introduced.

Finally, when slave owners exercised little or no influence at constitutional conventions, proslavery delegates could not influence drafting decisions. Even though slave owners might have wanted compensation guarantees, they were not able to secure those protections. The hegemonic preservation thesis does not eliminate other potential motives supporting compensation. As historical scholarship makes clear, property owners more generally demonstrated concerns about confiscation throughout the colonial and antebellum period (Ely 2008). The slavery hegemonic preservation argument therefore simply holds that these specific factors-slave owners were present and threatened-are themselves sufficient, though not necessary, for determining whether a constitution will contain a compensation clause. The slavery hegemonic preservation thesis does not make predictions about compensation clauses in conventions where slave owners were not present. Nonetheless, this category of cases serves as a useful basis for comparison to assess slavery's impact.

\section{METHODOLOGY}

The origins of compensation clauses in US constitutions have been notoriously difficult to establish. At the federal level, the Fifth Amendment's compensation clause is the only provision of the Bill of Rights that did not receive consideration either in the First Congress or at any of the state ratifying conventions (Treanor 1995, 791). At state constitutional conventions, delegates never recorded the debates and proceedings of committees charged with drafting bills of rights. Instead, the text of the constitutions themselves, the records of debates and proceedings of the convention as a whole, and secondary sources provide the best sources available to determine whether a relationship exists between slavery and just compensation.

But the quality of this evidence varies. For example, the text of the Lecompton Constitution contains sufficient evidence to support the hypothesized relationship between slavery and just compensation because drafters included an explicit provision guaranteeing compensated emancipation (Kansas [Lecompton] Constitution of 1857 [Failed], Art. VII, § 2). Compensation clauses that did not mention slavery

7. There were, of course, many people — and not just the largest plantation owners—who were committed to the system of slavery. Indeed, historians, especially those who have explored sexual relationships in the US South (Salmon 1989; Bynum 1992; Bardaglio 1995; Hodes 1999), have demonstrated the existence of a more "organic" system where many were invested in maintaining the racial and gender hierarchies of the period, often distinguishing themselves in the hierarchy institutions by asserting their property rights (McCurry 1997, 17; Edwards 2009). Such findings are consistent with other arguments emphasizing the psychological benefits that racism and white supremacy bestow on poorer white men (Roediger 2007) and their demobilizing effects across racial lines (Morgan 1975). But when plantation owners were present at drafting conventions, they often succeeded in modifying constitutional rules so that they would be the primary political guardians of the slave economy. Those rules, as discussed below, often explicitly required a financial stake in slaves, or thinly disguised requirements that officeholders retain a financial stake in large estates, like slave plantations. This study therefore focuses on slave owners because they were often explicitly designated as the system's guardians. 
explicitly may nonetheless have been supported by proslavery delegates who instead supported a generic compensation clause with the expectation that it protected human property. In these instances, we will not necessarily find a "smoking gun" in the text of the constitution. Rather, we must rely on what David Collier (2011, 825) has referred to as "hoop tests," necessary for establishing, but individually insufficient for supporting, a relationship between slavery and compensation. The relationship is tested here by using process tracing techniques (Bennett 2010) to uncover specific types of evidence, described in greater detail below. To the extent that the proposed inquiry produces consistent results across a diverse range of conventions, this inquiry should amount to a compelling-though never wholly dispositive-method for inferring a more general relationship between slavery and just compensation in antebellum US constitutionalism.

Three pieces of evidence are particularly important to support the argument advanced here. First, each case study assesses the level of influence of proslavery delegates. For obvious reasons, we should not expect to see evidence of a delegate's influence on constitutional texts unless he had representation at a constitutional convention.

Second, if proslavery delegates were present, they behaved differently according to their estimations of their own political futures, or slavery's. If proslavery delegates believed that future rules governing office holding preserved their control, then they had little use for compensation clauses. Similarly, if they did not perceive the institutions of slavery as threatened, then they had similarly little use for compensation clauses. Such provisions, as discussed, introduced risks they wished to avoid.

If, however, the institutional arrangement seemingly did not preserve slave owners' control of government or, relatedly, new threats to slavery caused slave owners to conclude that existing control was insufficient, then they had strategic reasons to adopt compensation clauses. Indeed, these two conceptually distinct threats often occurred simultaneously. In many states, new western settlers, who were on the whole less committed to slavery, demanded a broader franchise and more favorable legislative apportionment, potentially reducing slave owners' control over government. Without control of government, slave owners might have expected that slavery would not last long either. In other instances, increasing national controversy over slavery during the nineteenth century might have caused slave owners to perceive new threats even though they retained control of government. Abolitionist agitation, for example, may have caused southern slave owners to alter their strategic calculations and to support compensation clauses.

Evidence to test the hypothesized relationship between slavery and compensation was drawn from eighty-one antebellum US state constitutions drafted between 1776 and 1860. Constitutions were taken from Horst Dippel (2006). This database includes constitutions from thirty-six states and six other political entities that never achieved statehood (Tables 3, 4, and 5). The data set also includes twentythree "failed" constitutions that were drafted but never implemented. Once a state adopted a compensation clause, subsequent observations for that state were dropped because historical evidence suggests that property protections generated their own constituencies of support, altering the dynamics at subsequent drafting conventions 
(Brown 1889, 234). That evidence is consistent with other institutionalist approaches, which suggest that an institution does not necessarily disappear simply because the original coalition that supported it changed (Orren and Skowronek 2004). Constitutional documents, convention debates, and secondary sources were examined and coded for theoretically relevant criteria. Primary sources were collected from a list identified by John Dinan (2006a, 279-85). Debates were digitized and searched for issues related to property and slavery, including whether slave owners expressed any concerns about their abilities to preserve their interests. Secondary sources about conventions were also consulted to determine whether proslavery delegates were present, whether they were satisfied with existing constitutional rules, or whether new rules threatened their control or new threats to slavery caused them to reevaluate slavery's future..$^{8}$ The presence of slave owners was often reported in secondary sources, ${ }^{9}$ or from the slave population of the delegates' districts, made available in secondary sources or by the US Census.

Secondary accounts were surveyed to determine whether slave owners' perceptions of their own political prospects or slavery's future were threatened. A comparison of Mississippi and Arkansas may be useful here to illustrate coding decisions. These states' constitutions barred emancipation, but only Mississippi's constitution also guaranteed compensation. Secondary sources discuss slave owners' political prospects and whether slavery's future was threatened. In Mississippi, fourteen separate counties sent delegates to the convention that drafted the Constitution of 1817. The delegate selection formula substantially favored five plantation counties-Adams, Claiborne, Jefferson, Warren, and Wilkinson-such that more than half the delegates represented these slavery counties. In John Winkle's $(2014,2)$ assessment, the convention's plan "reinforced sectional differences between eastern liberals from the Piney Woods and western conservatives." Subsequent legislative apportionment would not necessarily continue to favor these plantation counties, a cause for concern among slave owners. Such concerns were notably absent from Jesse Turner's study of the Arkansas convention nearly two decades later. By 1835, when Arkansas citizens were considering whom to send to the convention, Turner reported that there "were very few men, indeed, in the Arkansas of that day who were seriously opposed to slavery as an existing institution" (1911, 100). Therefore, slave owners had little cause for concern, even though convention representation was drawn evenly from across the state and not disproportionately from plantation counties as it had been in Mississippi. Similar analysis was conducted for all antebellum constitutional conventions.

It should be noted that the focus on slave owners alone works against the argument presented here. Many of slavery's opponents advocated compensation even if they endorsed abolition. In fact, the two positions were not just consistent for Henry Clay and Abraham Lincoln, but necessary, unless the country was at war

8. Coding decisions and citations to primary and secondary sources for each convention are available in an online supplement to this article.

9. Dan Friedman $(2011,2)$, for example, lists the members of the drafting committee and the districts they represented on the Eastern Shore and southern Maryland, regions where slavery predominated; and Malcolm Cook McMillan (1951), who notes that slave owners dominated Alabama's constitutional drafting committee. 
TABLE 2.

Compensation Adoption Rates (\%), by Influence and Threat

\begin{tabular}{lcr}
\hline Proslavery Delegates & Adoption Rate (\%) & N \\
\hline Present, and & & 21 \\
Threatened & 86 & 24 \\
Not threatened & 13 & 36 \\
Absent & 64 &
\end{tabular}

$$
\chi^{2}=26.6 ; p<0.001
$$

(Foner 2010; Oakes 2013). Constitutional drafters who opposed slavery may have reached similar conclusions about government's capacity to interfere with slavery, ${ }^{10}$ but because drafters did not keep systematic records of committee debates or votes on just compensation clauses, this constitutional evidence about the relationship between slavery and compensation has often been lost to history. The method adopted here can support an inference about slavery's influence on compensation clauses despite this missing evidence if slave owners' behavior alone suggests a correlation between compensation clauses and slave owners' strategic drafting behavior.

The dependent variable, the presence of a compensation clause, was assessed as follows. Each constitution was examined to determine whether governments were required to pay compensation if they confiscated private property. These guarantees came in a variety of forms, especially before 1790 (Table 1). Some constitutions, such as North Carolina's, recognized certain limitations on the government's capacity to confiscate property (North Carolina Declaration of Rights of 1776, $\S$ 12) but the constitution did not go as far as to guarantee compensation. Only those constitutions that ensured money or compensation were coded as containing compensation clauses.

\section{SLAVERY'S INFLUENCE ON CONSTITUTIONAL DRAFTING}

Antebellum constitutions largely conform to the predictions that follow from hegemonic preservation theory regarding compensation clauses and slavery. Table 2 demonstrates the different adoption rates according to the influence of proslavery delegates at each convention. When proslavery delegates felt that slavery was threatened, they adopted compensation clauses at high rates (86 percent). When proslavery delegates did not exercise any influence, other drafters regularly included compensation clauses (64 percent). However, when proslavery delegates exercised decisive control over constitutional drafting, they largely avoided compensation

10. Compensation guarantees often appeared in northern constitutions alongside post-nati emancipation schemes, as they did in the Vermont Constitution of 1777. Some scholars, such as Manisha Sinha $(2016,65)$, have noted such relationships as courts attempted to work out the competing property rights of various parties. In these plans, sometimes courts awarded slave owners compensation; sometimes states mandated self-purchase and apprenticeship to protect slave owners without burdening the state with costs; and sometimes slaves were the recipients of compensation. 
guarantees (13 percent). The chi-squared test $\left(\chi^{2}=26.6\right)$ of the two-way contingency table is statistically significant $(p<0.001)$ and consistent with the predictions of hegemonic preservation theory.

Along with aggregate statistical evidence about adoption rates, case studies provide supporting evidence about the relationship between slavery and compensation. In this section, I present more detailed dynamics of state constitutional drafting histories to demonstrate the political dynamics that caused constitutional drafters to adopt or forego compensation clauses. The cases were selected to demonstrate the full, diverse range of outcomes in constitution making while accounting for the most difficult cases across the South Atlantic (Gerring 2008, 647). Two cases in particular, Virginia and Maryland, were selected because they exhibit important within-case variation, demonstrating how changes in political context influenced some constitutional drafters.

\section{South Carolina: Proslavery Delegates Avoided Compensation Clauses}

South Carolina was one of several states where slave owners were confident about their political power and avoided compensation clauses (Table 3). Although South Carolina held several drafting conventions, delegates did not include a compensation clause at any point during the antebellum period. Its Constitution of 1778 , for example, guaranteed certain "due process" protections, holding that "no Freeman ... [be] disseised of his freehold liberties or privileges ... or deprived of his life liberty or property but by the Judgment of his Peers or by the law of the Land" (Art. XLI). The common law provided property owners some protection for condemnation. As the antebellum period's most prominent legal theorist Chancellor James Kent (1826) recognized, the common law guaranteed compensation for internal improvements, ${ }^{11}$ but legislative decisions to abolish slavery would supersede common law protections, indicating why proslavery delegates might have sought constitutional protections. But they did not do so in South Carolina.

The absence of a compensation clause did not seem to bother delegates-or slave owners-such as John Rutledge, South Carolina's future governor. Instead, proslavery delegates were far more concerned with the franchise. Many delegates believed that all adult, white, Christian men should be entitled to the vote (Edgar 1998). Rutledge and other conservatives disagreed, arguing that only property owners were sufficiently immune from corruption to make governing decisions for South Carolina. Rutledge went as far as to resign from the convention because he believed his colleagues were misguided. Most white, Christian men in South Carolina during this period did not own slaves and, therefore, did not have a financial stake in the economic system. Without such ties, Rutledge worried, proslavery delegates might introduce uncertainty into the political system.

11. He asserted that " $[\mathrm{r}]$ oads may be cut through the cultivated lands of individuals without their consent, provided it be done by town officers of their own appointment, upon the previous application of twelve freeholders; and the value of the lands, and amount of the damages, must be assessed by a jury, and paid to the owner" (Kent 1826, 339). 
TABLE 3. Slavery Constitutions

\begin{tabular}{llc}
\hline Year & \multicolumn{1}{c}{ State } & Compensation \\
\hline 1776 & Delaware & No \\
1776 & Georgia & No \\
1776 & Maryland & No \\
1776 & New Jersey & No \\
1776 & North Carolina & No \\
1776 & South Carolina & No \\
1776 & Virginia & No \\
1777 & Georgia & No \\
1777 & New York & No \\
1778 & South Carolina & No \\
1789 & Georgia & No \\
1790 & South Carolina & No \\
1792 & Maryland & No \\
1798 & Georgia & No \\
1812 & Florida (East ${ }^{\dagger}$ & No \\
1817 & Florida & No \\
1823 & North Carolina & No \\
1833 & Texas (San Felipe de Austin) & $\dagger$ \\
1835 & North Carolina & No \\
1836 & Arkansas & No \\
1810 & Florida (West) & No \\
1835 & Texas (Interim) & Yes \\
1836 & Texas (Interim) & Yes \\
\hline
\end{tabular}

${ }^{\dagger}$ Failed constitution.

Rutledge's side ultimately prevailed on this issue. South Carolina's Constitution of 1778 imposed a relatively burdensome property requirement, requiring that voters possess "a free hold at least of fifty acres of land or a Town lot" (Art. XIII). Such property requirements only favored slave owner's hold on political power. Just to be sure, the constitution also required that representatives possess at least "seven thousand pounds currency" and "a settled Estate," all but guaranteeing that the representative held a stake in the plantation economy (Art. XII). Even if most of South Carolina's white adult men had hoped to elect an antislavery representative, it seems unlikely that they would find a suitable candidate on the ballot. Instead, voters would select from among slave owners such as John Rutledge, who was elected governor in the following election.

Rutledge could afford the luxury of resigning from the convention because he had little reason to fear for the future of slavery. In South Carolina, as in other major slave economies along the South Atlantic coast, slave owners had protected their investments through institutional control (Davis 2006, 136; Graham 2011). Slavery had developed alongside the colony's political institutions, and planters were well accustomed to the rules when the state drafted its first constitutions. By 1776, its slave population already exceeded 75,000 people, with slaves outnumbering whites along the coast where the planter class exercised its strongest political influence 
(Davis 2006, 136). The 1778 constitution also allocated 138 seats in the General Assembly to these "low-country" representatives. The remaining sixty-four seats went to "up-country" districts, where slavery was less prominent (Edgar 1998, 255). Even then, however, these up-country representatives were still required to comply with the constitution's property requirements for office. Legislative control provided immediate safeguards for slavery. Constitutional rights, therefore, were less urgent.

Drafters imposed similar requirements in South Carolina's subsequent antebellum constitutions. When South Carolina redrafted its constitution in 1790, planters only further entrenched their hold on legislative office. The new constitution obliged all House members to own at least ten slaves or real estate holdings exceeding $£ 150$. Senators were subject to more stringent requirements (South Carolina Constitution of 1790 , Art. I, $\S \S 6,8)$. Therefore, despite nominally expanding the franchise to all white adult males, the state constitution required that representatives participate in the slave economy or hold a large stake in that economic system (Wilentz 2005, 82-83).

The divisions between slavery's low country and up country diminished after 1808. When South Carolina revised its constitutional document in 1808 with the help of newly elected members such as John C. Calhoun, slavery had spread into South Carolina's backcountry. Eli Whitney's cotton gin created, in the words of one historian, a "statewide planter elite, composed increasingly of former outsiders like John Calhoun but united in its endorsement of established low-country interests, above all slavery" (Wilentz 2005, 146). Considering South Carolina's rules governing representation, South Carolina planter-and future governor-James Hammond remarked that the planter class had all the power; the "people [had] none, beyond electing members of the legislature" (341). Therefore, according to historian Stephanie McCurry, "[l]owcountry planters had nothing to fear" from the representatives from South Carolina's middle and up country because those planters were equally committed to slavery and equally confident they could exclude yeoman framers from legislative office (McCurry 1997, 35). The planter elite went as far as to expand white manhood suffrage two years later, seemingly because the institutional arrangement preserved their authority in the face of democratization (McCurry 1997, 35).

Of course, any argument about the relationship between compensation and slavery would be implausible if constitutional drafters did not recognize the possibility of using compensation as a safeguard. In South Carolina, members of the political elite were acutely aware of the ways that compensation protected slave owners. During the Revolutionary War, many states contemplated emancipation if slaves contributed to the war effort (Kaminski et al. 2009, 1504; Sinha 2016, 49). South Carolina was no exception. Under the Articles of Confederation, South Carolina had to supply soldiers to staff the state's militia, but it regularly fell short of its recruitment quotas. When faced with one particularly egregious shortfall, Governor John Rutledge and the legislature proposed enlisting 3,000 slaves to be "commanded by white officers, with Congress compensating the owners up to $\$ 1,000$ for each Negro man of 'standard size' not older than 35 years of age, who enlisted for the duration of the war and passed muster" (Foner 1975, 331). When the state's legislature considered the implications of arming slaves to staff their militias, however, slave owners withdrew their support and the plan never materialized (Davis 2006, 148). Subsequently, slaves served only in supporting militia roles. 
Although places such as North Carolina, South Carolina, Georgia, and-for a time-Virginia and Maryland differed in many respects, their constitutional histories reveal a similar pattern. Slave owners were well represented at constitutional drafting conventions throughout the entirety of the antebellum period, and they used these opportunities to entrench themselves further in their respective states' elected governing institutions. When threats to their personal property emerged, they were subsequently well positioned to deal with those threats. Like their counterparts in other South Atlantic states, proslavery delegates did not see a need for South Carolina's slave owners to insist on a compensation clause, even though they often adopted other rights in the state's constitutions and pioneered other constitutional arguments to preserve slavery (Sinha 2000, 2). This varied commitment to rights further supports the conclusion that constitutional drafters were not always motivated by Lockean ideals of limited government, to the extent that they were at all.

\section{Virginia: Threatened Slave Owners Adopted a Compensation Clause}

By introducing substantial property and slavery requirements for representatives, South Carolina's constitutional drafters could protect slavery, even to the point where some slave owners considered impressing slaves into militia service. In other states, however, the planter class sometimes was less successful at countering rising democratic demands. Under these circumstances, compensation clauses afforded additional protection (Table 4).

In Virginia, for example, constitutional drafters initially placed substantial restrictions on the franchise. In Virginia's Constitution of 1776, only those who owned a fifty-acre freehold were entitled to vote (Wilentz 2005, 199), a requirement that augmented the electoral power of the planter class relative to the overall population. By 1780, Virginia's legislature had debated a plan to encourage white enlistment in the state's militia by redistributing property, including slaves, from Virginia's planter elite (McDonnell 2006, 305-06). Firmly in control of the legislature, proslavery representatives from the Tidewater were ultimately able to thwart such a plan. The few political elites who opposed slavery largely believed that the best way to rid Virginia of its "peculiar institution" was a natural, economic death. Agitation, these moderates believed, would only prolong slavery's future by hardening the resolve of Virginia's planter class (Wilentz 2005, 220). With their political power secure, Virginia's planters were confident that the state's elected institutions would provide sufficient protection against slavery.

The constitution's property guarantees reflected their confidence. Virginia's Declaration of Rights (1776) guaranteed that its citizens could not be "deprived of their Property for Publick Uses without their own Consent or that of their Representatives" (Art. VI). That provision was virtually the same as South Carolina's, and it is consistent with the theory advanced here, namely, that slave owners had little reason to adopt compensation guarantees when they remained confident about their future political control.

By 1815, however, the state's democratic sentiments had changed. Severe restrictions on the franchise caused consternation among Virginia's non-freeholders. 
TABLE 4.

Threatened Slavery Constitutions

\begin{tabular}{llc}
\hline Year & \multicolumn{1}{c}{ State } & Compensation \\
\hline 1784 & Franklin $^{\dagger}$ & No \\
1785 & Frankland $^{\dagger}$ & No \\
1860 & Arizona $^{\dagger}$ & No \\
1792 & Delaware & Yes \\
1792 & Kentucky & Yes \\
1796 & Tennessee & Yes \\
1817 & Mississippi & Yes \\
1819 & Alabama & Yes \\
1820 & Missouri & Yes \\
1821 & New York & Yes \\
1830 & Virginia & Yes \\
1837 & Maryland & Yes \\
1839 & Florida & Yes \\
1843 & Oregon (Organic Law) & Yes \\
1845 & Louisiana & Yes \\
1845 & Oregon (Organic Law) & Yes \\
1845 & Texas & Yes \\
1846 & New Mexico & Yes \\
1857 & Kansas (Lecompton) & \\
1859 & Oregon & Yes \\
& Kansas (Wyandotte) & Yes \\
\hline & & Yes \\
\hline
\end{tabular}

${ }^{\dagger}$ Failed constitution.

*Constitutional amendment.

Groups in western parts of Virginia began to petition the state's legislature, demanding that the state abandon or otherwise decrease property requirements on the franchise, or else reallocate representation to reflect the growth of Virginia's population west of the Alleghenies. The western region's population, far less dependent on slavery, had increased by 40 percent while the population had remained almost stagnant in the Tidewater (Wilentz 2005, 34; Dinan 2006b).

When petitions did not bring about the intended result, Virginia's western counties met in Stanton in 1825 to protest the malapportionment of the state's legislature. Delegates at the meeting drafted a protest constitution, challenging the political representation of Virginia's "slaveowning eastern aristocracy." Virginia's legislature ultimately capitulated to these demands, holding a public referendum in 1828 on whether the state should draft a new constitution. The referendum received overwhelming support.

Virginia held a convention for a new constitution in 1830. Among its delegates were some of the most noteworthy participants in antebellum American politics, including James Monroe, John Marshall, and James Madison. The Piedmont and Tidewater regions of the state-those regions reliant on slave labor-still dominated the appointment of delegates to the drafting convention (Wilentz 2005, 342), but even though these regions were overrepresented, these delegates faced tremendous difficulty forming strong coalitions at the convention. Planters such as Abel Upshur recognized that slave owners' "interests [were] not identical [to those in the west] and 
the difference between [them] arose from property alone"- a thinly veiled reference to slavery (343). Upshur's concern was founded on white westward migration within the state. Increased population in the west would reduce the relative strength of eastern plantation counties in the state legislature (Freehling 1982). The reduction of eastern influence concerned many at the constitutional convention, including $\mathrm{Mr}$. Richard Morris of Hanover, who drew out the consequences for slavery: "when these gentlemen [of the western parts of the state] get the power, they will pass a general emancipation law; but if they raise the tax on slaves, much higher than it is, one of two things must happen: either the master must run away from the slave, or the slave from the master" (Virginia State Convention 1830, 116).

In response to such fears, Morris explicitly articulated the compensatory requirements that he believed should constrain Virginia's government if it interfered with slavery. "This thing between master and slave [was] one which cannot be left to be regulated by the Government. Compensation for 400,000 slaves, can not be made. The matter must be left to the silent operation of natural causes" (Virginia State Convention 1830, 116). Slave owners like Morris believed that the obligations created by the compensation clause did not just protect the "fair value" of slave owners' investments, the compensation principle precluded any large-scale interference with slavery because the state could not afford to compensate slave owners (Freehling 1982). The records of the Virginia convention do not explicitly connect Morris's comments with the ultimate decision to include the compensation clause in the constitution. Nonetheless, it was the only debate about property compensation in the convention records (Virginia State Convention 1830), and rather than reissuing the same due process clause, the Virginia Constitution of 1830 held that the "Legislature shall not pass ... any law, whereby private property shall be taken for public uses without just compensation" (Art. III, § 11). Slaveholders in Tidewater and Piedmont counties ultimately secured a small representational "bonus" in Virginia's Constitution of 1830, gaining six more seats than might be expected under purely "republican" principles of equal apportionment (Freehling 1982, 123-24).

The new apportionment formula therefore offered slaveholders some protection, but the environment had clearly changed. The expansion of the slave-based economy across new southern states and in the territories had increased the value of slaves everywhere, causing Virginia's planters to sell their "property" to western buyers (Deyle 2006). For the first time in the state's history, the slave population began to decline (Berlin 1998, 369). Upshur and Morris may have been sensitive to these market pressures during the convention, though they could not have predicted Nat Turner's rebellion the following year. Nonetheless, Turner's rebellion placed slavery squarely on the Virginia legislature's agenda and confirmed slave owners' fears about controlling slave policy. While conservatives sought to use their legislative power to assure "due subordination" of all slaves in the state after Turner's attack on plantation owners, westerner reformers used the opportunity to push abolition onto the legislative agenda for the first time. In the past, eastern conservatives had been able to repel such attempts because of their legislative dominance, but when William Osborn Goode again tried to silence debate about abolition, he "produced the very debate" that the "slave party ... wished to avoid" (Freehling 1982, 135). 
In the two years following the convention, Virginia's legislature and Virginians more broadly debated emancipation. Those debates often turned on compensation. Thomas Jefferson Randolph, grandson of the former president, proposed a post-nati emancipation scheme for the state. Under the plan, the state would assume ownership of slaves born after 1840 once they reached the age of majority. The state would then hire out their labor to pay for their re-colonization (Ford 2011, 367-68). However, as Lacy Ford reports, Randolph's plan failed to secure compensation for Virginia's slave owners. Accordingly, the plan ran afoul of the constitution. In a famous proslavery letter by a prominent conservative Virginian, Benjamin Watkins Leigh asserted that the Constitution of 1830 served as an '“insuperable barrier' to uncompensated, 'compulsory' emancipation” (Freehling 1982, 200). Moreover, like Morris, Leigh claimed that Virginia was in no position to live up to its constitutional obligations under the compensation clause, estimating that abolition would cost the state nearly $\$ 100$ million.

That Morris and Leigh would appeal to the principle of compensated emancipation was hardly a surprise. During the antebellum period, slave owners repeatedly petitioned the Virginia legislature for compensation when the state contributed to the loss or death of slaves - even when the state's role in such occurrences was minimal. It was easy to understand why Eleanor Bowery issued a petition in 1788 asking for compensation after Virginia had impressed her slave, Cuffey, to serve aboard a ship during the Revolutionary War, ${ }^{12}$ but John Willoughby also petitioned the legislature for the loss of eighty-seven slaves who escaped his plantation and joined Lord Dunmore's British fleet. ${ }^{13}$ Jailers often requested compensation for maintaining captured slaves, but slave owners also petitioned the legislature for slaves who died in jail after being suspected of, convicted of, or executed for a crime. ${ }^{14}$ Some slave owners even requested compensation for slaves who were killed by the government as part of Nat Turner's rebellion, the same year that Virginia adopted the compensation clause. ${ }^{15}$ The Virginia archive contains a host of similar petitions, demonstrating that the legislature provided regular recourse for slave owners, even when the state's own role in the loss of the slave was marginal. The newly adopted compensation clause only strengthened the claims of future petitioners, even if western delegates exercised increasing control in the Virginia legislature.

Unlike these small-scale compensation petitions, however, Virginia's compensation clause went beyond concerns about fair value in the emancipation debates of 1831. Just compensation operated to prevent the legislature from pursuing emancipation by shifting the costs of liberation back onto the state's treasury. To be sure, this property right restricted government, but only from pursuing an emancipating policy agenda. It is difficult to square just compensation in this instance with its conception

12. Legislative Petitions of the General Assembly, 1776-1865, Accession Number 36121, Box 65, Folder 17.

13. Legislative Petitions of the General Assembly, 1776-1865, Accession Number 36121, Box 181, Folder 4.

14. In 1829, just before the constitutional convention, Thomas Baker sought compensation for his slave, Gabriel, who was executed for rape. Legislative Petitions Microfilm Reel 151, Library of Virginia, Richmond, VA.

15. The estate of Elizabeth Turner sought compensation for the loss of her slave Jordan, who was killed during the rebellion. Legislative Petitions of the General Assembly, 1776-1865, Accession Number 36121, Box 234, Folder 83. 
as a Lockean right designed to preserve liberty. Property rights instead were used to preserve a system of power and hierarchy, consistent with scholarship critical of property rights and ascriptive hierarchies in the US constitutional tradition (Cover 1986; Harris 1993; Smith 1997; Sharfstein 2012). Moreover, when compared to South Carolina's delegates, the decision of Virginia's proslavery delegates to support just compensation should be understood as the product of a set of short-term calculations about how best to preserve their interests in response to democratization.

\section{Maryland: Threatened Slave Owners Adopted a Compensation Clause}

Maryland's constitutional amendment of 1837 offers important evidence of the relationship between slavery and compensation. Like Virginia and other states in the Old South, Maryland's political institutions had developed alongside slavery during the colonial period. Its slave population was already substantial by the time the colony declared independence in 1776 (Berlin 1998, 369), and planters largely controlled those institutions and the state's drafting convention (Friedman 2011, 2). Therefore, proslavery officials may not have wanted to limit themselves with respect to property or else invite a constitutional theory that implicitly endorsed emancipation. The state's original takings clause, in Maryland's Declaration of Rights of 1776, recognized:

That no freeman ought to be taken, or imprisoned, or disseized of his freehold, liberties or privileges, or outlawed, or exiled, or in any manner destroyed, or deprived of his life, liberty or property, but by the judgment of his peers, or by the law of the land. (Maryland Declaration of Rights of 1776, Ch. I, § 8)

Large property requirements for office holding ensured that slave owners could expect to control legislative power for the foreseeable future.

As Maryland's slave economy started to change, however, the political calculations of planters also changed. Like Virginia, Maryland's northern and western counties were not similarly committed to slavery as their southern and eastern counterparts (Fields 1985, 1-16). These divergent free and slave-labor economies encouraged political representatives from respective parts of the state to advocate different interests, but Maryland's Constitution of 1776 favored slave owners. Each county sent four representatives to the House of Delegates, favoring the more sparsely populated slave counties on the Eastern Shore and in southern Maryland (Maryland Constitution of 1776, Art. 2). The constitution apportioned the Senate in ways that further benefited slave counties. The Eastern Shore, dominated by slavery, was awarded six senators, while the remaining territory received nine (Art. 15). Of course, southern Maryland, also dominated by slavery, contributed votes and representatives to this region. Just to be sure, the Constitution of 1776 also required that any representative retain a substantial stake in Maryland's mixed economy. Delegates were eligible to serve only if they maintained an estate of five hundred pounds; senators had to maintain an estate of one thousand pounds (Art. $2,15)$. 
After 1790, Maryland's population expanded westward into regions not intimately tied to slavery (Fields 1985; Friedman 2011). These largely cereal farmers increasingly demanded legislative reapportionment, and their demands coincided with intervention from abolitionist provocateurs during the 1830s, who had taken control over northern state legislatures. These northern abolitionists had begun to bombard Maryland with abolitionist petitions. New York and Maine, for example, sent formal petitions to Maryland requesting that the state legislature abolish slavery.

These petitions did not have their intended effect. Instead, they hardened the resolve of many of Maryland's slave owners. Governor Thomas Veazery, himself a planter and committed advocate of slavery, made a recommendation to Maryland's General Assembly that it take constitutional steps so that it be "made known, that we can not recognize in any of our sister States, or their citizens, any right to interfere with our slaves; and that we unequivocally deny any authority in the general Government to legislate upon the subject of their emancipation, or to disturb our rights of property in them in any manner whatsoever" (Veazey 1836, 12, 14). Those powers presumably rested with Maryland's legislature. On February 14, 1837, Mr. Benjamin G. Harris, member of Maryland's General Assembly representing St. Mary's County, responded to his governor's call by introducing a constitutional amendment for a compensation clause, holding:

That the relation of master and slave, in this State, shall not be abolished unless a bill so to abolish the same, shall be passed by a unanimous vote of the members of each branch of the General Assembly, and shall be published at least three months before a new election of delegates, and shall be confirmed by a unanimous vote of the members of each branch of the General Assembly, at the next regular constitutional session after such new election, nor then, without full compensation to the master for the property of which he shall be thereby deprived. (Maryland Constitution of 1776, Amendment II of 1837, § 26, emphasis added)

The provision introduced extensive safeguards for slavery and then ultimately afforded slave owners compensation should all the remaining safeguards fail. In both Virginia and Maryland, the shifting economy and threats to slavery caused lawmakers to embrace compensation as a constitutional strategy for protecting slave owners.

Maryland, like Virginia, demonstrates the necessary steps that contributed to the adoption of compensation clauses in state constitutions. Like South Carolina, planters in Virginia and Maryland exercised disproportionate influence at the eighteenth-century conventions. Even if they encountered threats to slavery because of the Revolutionary War, they were still well positioned to counter those threats through existing political institutions, but as the dynamics of slavery changed during the nineteenth century, the planter classes in these states had to alter their calculations. In Virginia, those pressures followed westward democratic expansion. In Maryland, however, the threat came from northern abolitionists, who sought to realize the emancipatory promises of democracy in a different way. Nonetheless, Maryland's lawmakers responded similarly, by turning to just compensation to preserve their interests in the existing hierarchical and ascriptive order. 


\section{Kentucky: Threatened Slave Owners Adopted a Compensation Clause}

In states such as Maryland and Virginia, planters had long controlled political power, and only adopted compensation clauses to preserve their interests in the face of political uncertainty. In many states, especially those created from the territories and an expanding population, slavery had not developed alongside the territory's political institutions. Instead, planters moved to the region and participated in drafting conventions alongside delegates strongly opposed to slavery (Ford 2011, 39). Compensation clauses afforded planters insurance in these circumstances (Coward 1979, 37), as they had for Maryland and Virginia's planters later in the antebellum period.

These dynamics were evident in places such as Mississippi, where the growth of cotton created tremendous demand for forced labor, ${ }^{16}$ but they also occurred earlier, in places such as Kentucky, where tobacco planters similarly relied on slave labor to facilitate the growth of an emerging tobacco markets. Constitutions in these states regularly contained at least one compensation clause (Table 4). Sometimes, they contained a second compensation clause explicitly linked to slavery. For example, the Kentucky Constitution of 1792, particularly illuminating given its temporal proximity to the drafting of the US Bill of Rights (1791), declared that:

[The] legislature shall have no power to pass laws for the emancipation of slaves without the consent of their owners, or without paying their owners previous to such emancipation a full equivalent in money for the slaves so emancipated. (Kentucky Constitution of 1792, Art. VIII, § 1)

This provision largely prevented Kentucky's state legislature from exercising its authority to regulate slavery and further saddled the state with the costs of emancipation.

Proslavery delegates sought these guarantees because slavery's future was in considerable doubt prior to statehood. Kentucky was formed out of the western portion of Virginia, and Kentucky's planter class planned to use forced labor for tobacco agriculture, but the region did not have a long history with slavery (Berlin 1998, 369). Rather, slavery in Kentucky was as new as the newly formed state's political institutions when compared with the colonial histories of slavery in South Carolina, Virginia, and Maryland. Yet despite Kentucky's relatively low slave population, slaves constituted about sixteen percent of the state's total population by 1790. Planters, as these statistics suggest, had made significant investments in human labor, which they would seek to protect against abolitionists.

Planters encountered threats to slavery almost immediately. For example, writing under the pseudonym "Scaevola," Henry Clay recommended a state constitution that gradually eliminated slavery in Kentucky (Aron 1996, 93; Wilentz 2005). Nor was Clay alone in his opposition to slavery. Virginia's western territory offered religious minorities such as Presbyterians, Methodists, Baptists, and Roman Catholics religious freedoms (Brown 1889, 51-52). Many in these churches opposed slavery,

16. Mississippi's constitution made such assurances (Mississippi Constitution of 1817, Art. I, § 13). 
and their congregations provided an organizational base on which to mobilize. Rev. David Rice, the head of the Presbyterian Church and himself a slave owner (Aron 1996, 89-90), was perhaps Kentucky's the most prominent abolitionist during this period. He regularly published pamphlets encouraging abolition, often based on religious appeal (Rice 1792; Sinha 2016, 93). Rice eventually entered politics with the hopes of eliminating slavery from the future state.

Security issues had driven many Kentuckians to seek independent statehood. Virginia either could not afford or refused to pay for additional armaments to protect Kentucky's settlers from Native American raids. Kentucky's settlers petitioned Virginia for independent statehood, arguing that they would be better able to protect themselves - and pay for their own security - if they were separate from Virginia. Virginia agreed, but made independence conditional on the drafting of a new constitution that protected slavery. Some Virginians, perhaps most notably the future US Attorney General, John Breckinridge, were reluctant to transport their slaves into the territory (Ford 2011, 39). Breckinridge admitted that he was "somewhat afraid of the Kentucky politicians with respect to negroes" (Aron 1996, 91). Nor were Breckinridge's fears misplaced. Rice, along with another leading abolitionist-the Honorable Harry Innes-sought to abolish slavery at the constitutional convention and to encourage democratic influence more generally (Coward 1979, 12-47).

Despite mobilized opposition to slavery, slave owners enjoyed strong political backing from Virginia. George Nicholas, a prominent politician and lawyer in Virginia and himself a planter, was the intellectual force behind Kentucky's first constitutional convention. He was dedicated to protecting slavery in the future state and led Kentucky's proslavery coalition (Brown 1889, 228). Nicholas and other slave owners recognized that the existing electoral rules would endanger slaver owners and undermine slavery's future in Kentucky (Coward 1979, 17). Nicholas sought to uphold Kentucky's promise by introducing Article VIII-the slavery article and its compensation guarantee-to alleviate anxieties over abolition.

The legislature shall have no power to pass laws for the emancipation of slaves without the consent of their owners, or without paying their owners previous to such emancipation a full equivalent in money for the slaves so emancipated. (Kentucky Constitution of 1792, Art. VII, § 1)

The convention featured few contentious debates aside from those related to slavery and Article VIII (Brown 1889, 229). On this point, however, controversy divided the delegates (Ireland 2012, 3). A strong voting bloc of slave owners formed behind Rice in opposition to slavery and the compensation protections guaranteed by the slavery article (Brown 1889, 230 n1; Aron 1996, 90). But Nicholas ultimately prevailed by successfully drawing away three crucial votes from Rice's bloc. Like elites in other emerging slave states, Kentucky's proslavery elites did not control enough political power to insist on absolute rights in human property; instead, they sought to constrain the governing authority of the state's legislature by implementing a compensation clause. 
Efforts toward more democratic reforms emerged almost immediately after the adoption of Kentucky's Constitution of 1792 (Aron 1996, 90). Throughout these debates, Nicholas consistently appealed to Article VIII-the article he drafted-to remind Democrats of the state's obligations under the compensation principle (Nicholas 1799). The constitution, Nicholas argued, recognized slave owners' right to property; any interference with that right would have required compensation. Nicholas's behavior is consistent with other arguments that cast rights as devices for hegemonic preservation. Like his counterparts in Virginia and Maryland, Nicholas and other proslavery delegates were making short-term calculations about how best to preserve their interests and not necessarily carrying out deeply held commitments to Lockean principles.

\section{New Hampshire: Slave Owners Were Absent}

In states where slavery generated neither economic nor political power, slave owners were largely absent from constitutional conventions. Without influence on constitution making, the few slave owners in the state could do little to protect their interests. Although compensation clauses were not entirely absent in these constitutions, they were less likely than in places like Kentucky, and far more likely than in places like South Carolina (Table 5).

New Hampshire's constitutional history demonstrates how the dynamics of constitutional drafting differed in states without a strong slave presence. New Hampshire's Constitution of 1784, for example, guaranteed that "no part of a man's property shall be taken from him, or applied to public uses, without his own consent, or that of the Representative-body of the people" (New Hampshire Constitution of 1784, Art. VIII; New Hampshire Constitution of 1781 [Failed], Art. XII; New Hampshire Constitution of 1782 [Failed], Art. XII). The language of New Hampshire's early takings clause resembled the language of South Carolina's constitution, but New Hampshire's constitution also abolished slavery. ${ }^{17}$

With little representation and little economic stake, slave owners offered little resistance when New Hampshire abolished slavery. There seems to have been only one representative in the state legislature who had at any point owned a slave. William Whipple, perhaps most famous for representing his state in the Continental Congress, was a sailor during the middle of the eighteenth century. According to McClintock $(1889,420)$, Whipple had participated in the slave trade during his larger engagements with African trade, but he emancipated his slaves on the eve of the Revolutionary War. He subsequently refused to assist then-General Washington in the recovery of slaves in New Hampshire. By 1780, when he served as a member of the state assembly, there is no evidence that he was committed to the institution of slavery.

17. In his study, Nathaniel Bouton noted how the "Constitution of 1784, in its Bill of Rights, 'spake, and it was done.' Slavery vanished without noise, without a single known civil suit, without a ripple of disturbance or turmoil on the face of society" (Bouton 1877, iii-iv). The lack of opposition reflects the absence of slave owners in control of public power. 
TABLE 5.

Free Labor Constitutions

\begin{tabular}{|c|c|c|}
\hline Year & State & Compensation \\
\hline 1776 & New Hampshire & No \\
\hline 1776 & Pennsylvania & No \\
\hline 1778 & Massachusetts $^{\dagger}$ & No \\
\hline 1779 & New Hampshire ${ }^{\dagger}$ & No \\
\hline 1780 & New Ireland ${ }^{\dagger}$ & No \\
\hline 1781 & New Hampshire ${ }^{\dagger}$ & No \\
\hline 1782 & New Hampshire ${ }^{\dagger}$ & No \\
\hline 1784 & New Hampshire & No \\
\hline 1790 & Rhode Island & No \\
\hline 1792 & New Hampshire & No \\
\hline 1832 & Indian Stream Republic ${ }^{\dagger}$ & No \\
\hline 1841 & Rhode Island (Revised Statutes) $)^{\dagger}$ & No \\
\hline 1851 & New Hampshire ${ }^{\dagger}$ & No \\
\hline 1777 & Vermont & Yes \\
\hline 1780 & Massachusetts & Yes \\
\hline 1790 & Pennsylvania & Yes \\
\hline 1802 & Ohio & Yes \\
\hline 1816 & Indiana & Yes \\
\hline 1818 & Connecticut & Yes \\
\hline 1818 & Illinois & Yes \\
\hline 1819 & Maine & Yes \\
\hline 1824 & Rhode Island $^{\dagger}$ & Yes \\
\hline 1835 & Michigan & Yes \\
\hline 1841 & Rhode Island (People's Const.) ${ }^{\dagger}$ & Yes \\
\hline 1842 & Rhode Island (Landholder's Const.) & Yes \\
\hline 1842 & Rhode Island ${ }^{\dagger}$ & Yes \\
\hline 1842 & Rhode Island & Yes \\
\hline 1844 & New Jersey & Yes \\
\hline 1846 & Iowa & Yes \\
\hline 1846 & $\mathrm{Wisconsin}^{\dagger}$ & Yes \\
\hline 1849 & California & Yes \\
\hline 1849 & Deseret $^{\dagger}$ & Yes \\
\hline 1855 & Kansas (Topeka) ${ }^{\dagger}$ & Yes \\
\hline 1856 & Deseret $^{\dagger}$ & Yes \\
\hline 1857 & Minnesota & Yes \\
\hline 1858 & Kansas (Leavenworth) ${ }^{\dagger}$ & Yes \\
\hline
\end{tabular}

${ }^{\dagger}$ Failed constitution.

Without slavery on the political agenda, constitution making in New Hampshire differed from places such as Virginia and Kentucky. To be sure, issues of representation dominated New Hampshire's repeated attempts to draft a constitution (Marshall 2004). Delegates to the 1779, 1781, 1782, and 1784 conventions were allocated based on townships rather than absolute population. This method of apportionment favored the state's commercial centers in the southern and eastern parts of the states. However, because the constitution required general endorsements on a popular basis, all but the 1784 constitution received necessary support from the western portion of the state. Property concerns did not arise in the 
context of these debates. Instead, delegates were concerned that the state's governor would have sufficient authority to deal with the state's seemingly inevitable economic crisis (McClintock 1889, 409). Unlike in Kentucky, New Hampshire's delegates sought to increase governing authority over economic matters, not decrease it. Legal reform efforts dominated the 1792 convention. And even though New Hampshire witnessed significant debates about internal improvements after 1820 (McClintock 1889, 566-93), these debates did not cause constitutional drafters to adopt a compensation clause.

\section{ANALYSIS}

The preceding analysis establishes a relationship between just compensation and slavery according to various pieces of evidence. In the constitutions of states where slavery was relatively new, relatively prominent, but nonetheless politically vulnerable-like slavery in Alabama, Kansas [Lecompton], Kentucky, and Mississippi at the time of drafting-constitutional drafters made the relationship plain: lawmakers would have to pay slave owners if they chose to emancipate slaves (Alabama Constitution of 1819, Art. VI, Slaves, § 1; Kansas [Lecompton] Constitution of 1857 [Failed], Art. VII, § 2; Kentucky Constitution of 1792, Art. VIII, § 1; Mississippi Constitution of 1817 , Art. VI, Slaves, $\S 1$ ). The text of state constitutions in other southern states, such as Virginia and Maryland, did not establish the relationship as clearly. Nonetheless, convention and amendment debates strongly suggest that slave owners supported compensation clauses either when their hold on political power grew tenuous or when they encountered new threats to slavery that they had not anticipated. The compensation clause in these circumstances would have protected slave owners from a total financial loss in their investments while simultaneously discouraging state lawmakers from considering emancipation because of its financial costs.

Strikingly, the lawmakers of Virginia and Maryland did not adopt such provisions, despite the additional benefits compensation clauses afforded to slave owners before they encountered those threats. Before they encountered those threats, these lawmakers behaved more like constitutional drafters in South Carolina, who retained absolute control over government and therefore did not need to risk legitimizing a constitutional path for emancipation on a just compensation theory. Evidence from northern constitutional drafting conventions, such as New Hampshire's, suggests that controversies involving other types of property were often insufficient to support the adoption of compensation clauses. Although this evidence does not preclude the possibility that other motivations may have encouraged the adoption of compensation guarantees - as the Leavenworth Constitution makes explicitthese data suggest that slave owners strongly influenced the varied proliferation of these clauses when they were present at constitutional drafting conventions.

The adoption rate of compensation clauses is further consistent with the temporal and regional variation of the politics of slavery during the antebellum period. Figures 1 and 2 demonstrate drafters' increased willingness to adopt compensation guarantees in areas where, and during historical periods when, slavery was on the 
rise or on the decline (Berlin 2015; Sinha 2016). That evidence, of course, is consistent with some alternative explanations, but coupled with evidence about slavery debates, this regional and temporal variation is highly suggestive.

As already acknowledged, there are consequences to the decision to use "hoop tests" in the case studies. That decision is justified because the historical evidence will not support a systematic search for "smoking gun" evidence. However, that decision introduces some uncertainty about slavery's influence on the varied proliferation of compensation clauses in antebellum constitutions. I have attempted to minimize such uncertainty by demonstrating that the case study conclusions are consistent with aggregated patterns. Unless and until new sources of evidence emerge, the varied influence of slavery offers an important explanation for the varied origins of just compensation in antebellum state constitutions, with implications for how we should understand the compensation guarantees found in the Fifth Amendment to the US Constitution.

\section{IMPLICATIONS FOR THE US CONSTITUTION}

James Madison is well regarded for his influence on the US Constitution, recognized for his innovative constitutional theory elaborated in "Federalist No. 10," and remembered as a champion of liberty during the founding period. However, when he drafted and his colleagues adopted the Fifth Amendment in the First Congress, the evidence presented here suggests that Madison and his colleagues acted like Virginians. Constitutional drafting practices at the state level demonstrate that when the interests of slave owners were represented and they feared that political arrangements would not provide sufficient guarantees for slavery, then drafters adopted compensation clauses. These dynamics were present when the First Congress drafted the Bill of Rights.

The US Constitution, drafted in 1787 , did not mention slavery or explicitly protect the institution from federal interference. Nonetheless, the issue of slavery strongly influenced constitutional drafting decisions (Graber 2006). Most delegates agreed, however, that the US Constitution prohibited the federal government from interfering with slavery in the states, but permitted the federal government to promote slavery in the territories (Farrand 1966, 372) ${ }^{18}$ However, that position was not held unanimously. Opponents of the constitution highlighted how the new document could be interpreted to interfere with slavery in the states. At the Virginia ratifying convention, the slave owner and delegate to the US Constitutional Convention, George Mason, noted that there was "no clause in this Constitution to secure" slavery. Without such a clause, northern states could "lay such a tax as will amount to manumission" (Mason [1787] 2009, 1338). Institutional balancing rules, Mason feared, would not provide sufficient protection because "taxes on slaves would not affect the Eastern States" (1186) Mason reasoned:

18. The Fifth Amendment's Due Process Clause later served as a textual basis to invert this claim. Free Soilers such as Salmon P. Chase, for example, alleged that the Fifth Amendment prohibited the federal government from creating slavery anywhere in its jurisdiction, though it was still not permitted to interfere with slavery in the states (Foner 1995, 83). 
A tax that might with propriety be laid and with ease collected in Delaware, might be highly improper in Virginia. The taxes cannot be uniform throughout the States without being oppressive to some. If they be not uniform, some of the members will lay taxes, in the payment of which they will bear no proportion. The members of Delaware will assist in laying a tax on our slaves, of which they will pay no part whatever. (1186)

James Madison attempted to quell Mason's fears, arguing "that the same evil existed in some degree" under the Articles of Confederation (Madison [1787] 2009, 1186). However, Mason responded that, under the Articles of Confederation, the central government could only "say how much money [was] necessary, and to fix the proportion to be paid by each State." The central government could not "say in what manner the money [would] be raised. This [was] left to the State Legislatures" (Mason [1787] 2009, 1186).

The new US Constitution did not afford states similar discretion. Therefore, southern slave owners would be vulnerable to legislation that bore disproportionately on southern states. Madison's argument did not respond to this issue. Nor did Madison have convincing answers for Patrick Henry ([1787] 2009, 1341, 1476-77) and George Nicholas ([1787] 2009, 1341-42)—who would later preside over the drafting of Kentucky's constitution and author the influential Article VIII-when they made similar arguments about how the central government enjoyed greater powers under the new constitution that could interfere with slavery. ${ }^{19}$

The debates between Madison, Mason, and Henry demonstrate that Madison had occasion to think like a Virginian when the First Congress met to draft the Bill of Rights. In fact, the debate between Madison and Mason in many ways anticipated the compensation arguments of Hanover's Richard Morris at Virginia's own constitutional convention in 1830. Madison had similar reasons to support compensation forty years earlier. Some southerners were anxious about the scope of federal power under the new constitution. Presumably, a compensation clause might address some of those concerns if slave owners feared legislation that disproportionately bore on slavery.

Congress regularly compensated slave owners for the loss of slaves. For example, the issue of slave owner compensation remained a major point of emphasis during negotiations with the British and the drafting of the Jay Treaty (Sinha 2016, 51). The Senate ultimately requested that the president seek from the British "compensation for the negroes and other property, so alleged to have been carried away" (Read [1795] 1836, 861). Compensation was a regular feature of colonization, supported by Thomas Jefferson, James Monroe, and later presidents of the American Colonization Society, Madison and Henry Clay (American Colonization Society 1823, 5). Compensation also conditioned Congress's power to abolish slavery in Washington, DC before the Civil War (King and Smith 2011, 42-43). In

19. Consider Patrick Henry, who argued that the "majority of Congress is to the North, and the slaves are to the South. In this situation, I see a great deal of the property of the people of Virginia in jeopardy, and their peace and tranquillity [sic] gone away" (Henry [1787] 2009, 1477). 
fact, Congress largely respected this principle at least until the Second Seminole War. $^{20}$

Perhaps most importantly, the Continental Congress and First Congress adopted compensation clauses in legislation governing the future of slavery in the territories. When the Continental Congress enacted the Northwest Ordinance (1787), it included a compensation clause to protect property, including slaves (Finkelman 1989, 73-77). Article II held that no "man shall be deprived of his liberty or property, but by the judgment of his peers or the law of the land; and, should the public exigencies make it necessary, for the common preservation, to take any person's property, or to demand his particular services, full compensation shall be made for the same." The Northwest Ordinance organized the territory south of the Great Lakes and between the Ohio and Mississippi rivers, providing it with a governing structure. Until the states struck an eleventh-hour deal that abolished slavery in the region, it was largely expected that the compensation clause would protect existing slave holders from future state constitutional decisions about slavery's fate (Onuf 1987, 85-87). Southern states supported the expansion of slavery in principle. Virginia, for example, sought to promote the growth of non-Indian settlements in Ohio to buffer its Kentucky frontier against Indian attacks. However, states such as Virginia were reluctant to create greater competition for their own tobacco planters (111-12). During the final reading of the Northwest Ordinance, Virginia therefore put its support behind language abolishing slavery while simultaneously insisting on a fugitive slave clause, which better protected southern interests. Given the speed with which these developments occurred on the final reading of the Bill (Ford 1936, 313-20, 333), scholars have concluded that the contradictions between Article II and VI were not intended and that compensation applied to slavery (Finkelman 1989, 73-77).

The First Congress later used the Northwest Ordinance as a model for protecting slave owners' property rights in other territories. Congress adopted the identical compensation clause for protecting slave owners' property rights in the territories west of North Carolina and the Southwest Territories. ${ }^{21}$ In those statutes, Congress guaranteed that "the inhabitants of [the territory] shall enjoy all the privileges, benefits and advantages set forth in the ordinance of the late Congress, for the government of the western territory of the United States." 22 The only difference between these two statutes and the Northwest Ordinance (1787) was that "no regulations made or to be made by Congress, shall tend to emancipate slaves," but as the debates between Madison and the anti-Federalists made clear, Congress could enact

20. The US Army hired from Antonio Pacheco a slave named Lewis to serve as a guide (Foner 2010, 59). But when Lewis turned up in the hands of the Seminoles, Pacheco petitioned Congress for the cost of his slave. A group of US Representatives, led by Joshua R. Giddings, opposed compensation, arguing that while the constitution recognized the rights of slave owners in the states, it did not recognize rights to "human property" in places where the federal government exercised jurisdiction (Congressional Globe, 30th Cong., 2 d Sess. 239, 302). These data establish that until the 1840s, few disputed the notion that Congress faced obligations to compensate slave owners for the loss of their slaves.

21. An Act to Accept a Cession of the Claims of the State of North Carolina to a Certain District of Western Territory, 1 Stat. 106 (1790); An Act for the Government of the Territory of the United States, South of the River Ohio, 1 Stat. 123 (1790).

22. 1 Stat. $106,108(1790)$. 
statutes that bore disproportionately on slave owners. Therefore, while Congress deprived itself of the power to abolish slavery, the pattern suggests that the compensation clause protected existing and future slave owners in these territories from financial harms or if emancipation accompanied statehood.

Just like the dynamics that drove constitutional drafters to adopt compensation clauses in the states, proslavery members of Congress, first, had the power to influence the drafting of the Bill of Rights, and, second, feared that the existing institutional configuration offered insufficient protection for slavery. Moreover, the same members of Congress who adopted the Fifth Amendment used a similar provision to protect slave owners' investments in the territories. While little direct evidence reveals why the First Congress adopted the Fifth Amendment's compensation clause, circumstantial evidence suggests that they behaved like state constitutional drafters, who used compensation to protect the interests of vulnerable slave owners.

\section{CONCLUSION}

Property ownership and property rights are often portrayed as "safeguard[s] for political liberty," protecting individuals "against arbitrary government" in the US constitutional tradition (Ely 2008, xi). Such decidedly liberal portrayals of property rights are potentially misleading, at least as they apply to just compensation. Such accounts, which stress the value of liberty, are difficult to square with the decidedly illiberal impulses driving the decisions of many constitutional drafters to guarantee just compensation for government interference with slavery.

While compensation often protected individuals when authorities interfered with all kinds of private property, the constitutional proliferation of this guarantee was strongly influenced by a particular kind of property, namely, slavery. Slave owners sought to protect their investments at constitutional drafting conventions, but they varied in their strategies. When they were confident about slavery's political prospects, they avoided compensation clauses, fearing, presumably, that compensation might legitimize their opponents' positions. However, when proslavery drafters were anxious about their own political prospects, they were more likely to support the compensation principle, often including these provisions in the slavery sections of constitutions. This pattern suggests that property rights are not solely the product of-what we have come to call-liberal motives. Rather, these rights often and readily accommodated slave owners' illiberal goals to protect slavery.

With a few notable exceptions (Zackin 2010, 2013), US constitutional development - and the US Bill of rights in particular-has often escaped characterizations consistent with the hegemonic preservation thesis, but evidence about the origins of just compensation in US constitutionalism suggests that rights in the American tradition may not be so different from the development of rights abroad (Hirschl 2004). Like other elites who have faced increasing democratic pressures, American slave owners were often making strategic calculations about how they might best preserve their own interests. Sometimes, constitutional rights offered these elites an appealing alternative, but usually only after they believed that institutional alternatives were insufficient. Slave owners' varied willingness to embrace 
just compensation suggests that at least some aspects of American constitutional development may not be as exceptional as commonly portrayed.

\section{REFERENCES}

Ackerman, Bruce. We the People: Foundations. Cambridge, MA: Harvard University Press, 1991.

American Colonization Society. Sixth Annual Report of the American Colonization Society. Washington, DC: Davis \& Force, 1823.

Aron, Stephen. How the West Was Lost: The Transformation of Kentucky from Daniel Boone to Henry Clay. Baltimore, MD: Johns Hopkins University Press, 1996.

Bardaglio, Peter W. Reconstructing the Household: Families, Sex, and the Law in the NineteenthCentury South. Chapel Hill: University of North Carolina Press, 1995.

Bennett, Andrew. "Process Tracing and Causal Inference." In Rethinking Social Inquiry: Diverse Tools, Shared Standards, edited by Henry E. Brady and David Collier, 207-19. Lanham, MD: Rowman \& Littlefield, 2010.

Berlin, Ira. Many Thousands Gone: The First Two Centuries of Slavery in North America. Cambridge, MA: Harvard University Press, 1998.

- The Long Emancipation: The Demise of Slavery in the United States. Cambridge, MA: Harvard University Press, 2015.

Bouton, Nathaniel. Miscellaneous Documents and Records Relating to New Hampshire at Different Periods. Concord, NH: Edward A. Jenks, 1877.

Brown, John Mason. The Political Beginnings of Kentucky. Lexington, KY: J. P. Morton, 1889.

Bynum, Victoria. Unruly Women: The Politics of Social and Sexual Control in the Old South. Chapel Hill: University of North Carolina Press, 1992.

Collier, David. "Understanding Process Tracing." PS: Political Science E Politics 44, no. 4 (2011): $823-30$.

Cover, Robert M. "Violence and the Word." Yale Law Journal 95, no. 8 (1986): 1601-29.

Coward, Joan Wells. Kentucky in the New Republic. Lexington: University of Kentucky Press, 1979.

Davis, David Brion. Inhuman Bondage: The Rise and Fall of Slavery in the New World. Oxford: Oxford University Press, 2006.

Deyle, Steven. Carry Me Back: The Domestic Slave Trade in American Life. Oxford: Oxford University Press, 2006.

Dinan, John. The American State Constitutional Tradition. Lawrence: University Press of Kansas, $2006 \mathrm{a}$

. The Virginia State Constitution: A Reference Guide. Westport, CT: Greenwood Press, 2006b.

Dippel, Horst, ed. Constitutions of the World from the Late 18th Century to the Middle of the 19th Century Online. Munich: K. G. Saur, 2006.

Edgar, Walter. South Carolina: A History. Columbia: University of South Carolina Press, 1998.

Edwards, Laura F. The People and Their Peace: Legal Culture and the Transformation of Inequality in the Post-Revolutionary South. Chapel Hill: University of North Carolina Press, 2009.

Einhorn, Robin L. American Taxation, American Slavery. Chicago: University of Chicago Press, 2006.

Ely, James W. The Guardian of Every Other Right: A Constitutional History of Property Rights. Oxford: Oxford University Press, 2008.

Etchenson, Nicole. Bleeding Kansas: Contested Liberty in the Civil War Era. Lawrence: Kansas University Press, 2004.

"Where Popular Sovereignty Worked: Nebraska Territory and the Kansas-Nebraska Act." In The Nebraska-Kansas Act of 1854, edited by John R. Wunder and Joann M. Ross, 159-81. Lincoln: University of Nebraska Press, 2008.

Farrand, Max, ed. The Records of the Federal Convention of 1787. Vol.2. New Haven, CT: Yale University Press, 1966. 
Fields, Barbara Jeanne. Slavery and Freedom on the Middle Ground. New Haven, CT: Yale University Press, 1985.

Finkel, Jodi S. Judicial Reform as Political Insurance: Argentina, Peru, and Mexico in the 1990s. South Bend, IN: University of Notre Dame Press, 2008.

Finkelman, Paul. "Slavery and Bondage in the 'Empire of Liberty'." In The Northwest Ordinance: Essays on Its Formulation, Provisions, and Legacy, edited by Frederick D. Williams, 61-95. East Lansing: Michigan State University Press, 1989.

Fladeland, Betty L. "Compensated Emancipation: A Rejected Alternative." Journal of Southern History 42, no. 2 (1976): 169-86.

Foner, Eric. Free Soil, Free Labor, Free Men: The Ideology of the Republican Party Before the Civil War. Oxford: Oxford University Press, 1995.

—. The Fiery Trial: Abraham Lincoln and American Slavery. New York: W. W. Norton, 2010.

Foner, Philip S. History of Black Americans. Westport, CT: Greenwood Press, 1975.

Ford, Lacy K. Deliver Us from Evil: The Slavery Question in the Old South. Oxford: Oxford University Press, 2011.

Ford, Worthington C., ed. Journals of the Continental Congress, 1774-1789. Vol. 32. Washington, DC: US Government Printing Office, 1936.

Freehling, Allison Goodyear. Drift Toward Dissolution: The Virginia Slavery Debate of 1831-1832. Baton Rouge: Louisiana State University Press, 1982.

Friedman, Dan. The Maryland State Constitution: A Reference Guide. Oxford: Oxford University Press, 2011.

Gerring, John. "Case Selection for Case-Study Analysis: Qualitative and Quantitative Techniques." In The Oxford Handbook of Political Methodology, edited by Janet M. Box-Steffensmeier, Henry E. Brady, and David Collier, 645-84. Oxford: Oxford University Press, 2008.

Ginsburg, Tom. Judicial Review in New Democracies: Constitutional Courts in Asian Cases. Cambridge: Cambridge University Press, 2003.

Goodrich, Carter. Government Promotion of American Canals and Railroads, 1800-1890. New York: Columbia University Press, 1960.

Graber, Mark A. Dred Scott and the Problem of Constitutional Evil. Cambridge: Cambridge University Press, 2006.

Graham, Cole Blease. South Carolina State Constitution. Oxford: Oxford University Press, 2011.

Harris, Cheryl. "Whiteness as Property." Harvard Law Review 106, no. 8 (1993): 1707-91.

Hartz, Louis. The Liberal Tradition in America: An Interpretation of American Political Thought Since the Revolution. San Diego, CA: Harcourt Brace Jovanovich, 1955.

Henry, Patrick. "Debate Over the Constitution and Commentaries on the Virginia Convention, June-July 1788." In Documentary History of the Ratification of the Constitution, edited by John P. Kaminski, Gaspare Saladino, Richard Leffler, Charles H. Schoenleber, and Margaret A. Hogan, 10:1341. Charlottesville: University of Virginia Press, [1787] 2009.

Herron, Paul E. "Slavery and Freedom in American State Constitutional Development." Journal of Policy History 27, no. 2 (2015): 301-36.

Hirschl, Ran. Towards Juristocracy: The Origins and Consequences of the New Constitutionalism. Cambridge, MA: Harvard University Press, 2004.

Hodes, Martha. White Women, Black Men: Illicit Sex in the Nineteenth-Century South. New Haven, CT: Yale University Press, 1999.

Holt, Charles Frank. The Role of State Government in the Nineteenth-Century American Economy, 1820-1902: A Quantitative Study. New York: Arno Press, 1977.

Horwitz, Morton J. The Transformation of American Law, 1780-1860. Cambridge, MA: Harvard University Press, 1977.

Hurst, James Willard. Law and the Conditions of Freedom in the Nineteenth Century United States. Madison: University of Wisconsin Press, 1956.

Ireland, Robert M. Kentucky State Constitution. Oxford: Oxford University Press, 2012.

Kaminski, John P., Gaspare Saladino, Richard Leffler, Charles H. Schoenleber, and Margaret A. Hogan, eds. Documentary History of the Ratification of the Constitution. Vol.10. Charlottesville: University of Virginia Press, 2009. 
Kent, James. Commentaries on American Law. Vol. 2. New York: O. Halsted, 1826.

King, Desmond S., and Rogers M. Smith. "Racial Orders in American Political Development." American Political Science Review 99, no. 1 (2005): 75-92.

. Still a House Divided: Race and Politics in Obama's America. Princeton, NJ: Princeton University Press, 2011.

Lincoln, Abraham. "Second Annual Message." In The American Presidency Project. Online by Gerhard Peters/John T. Woolley, 1862. http://www.presidency.ucsb.edu/ws/?pid=29503.

Litwack, Leon F. North of Slavery: The Negro in the Free States, 1790-1869. Chicago: University of Chicago Press, 1961.

Madison, James. "Debate Over the Constitution and Commentaries on the Virginia Convention, June-July 1788." In Documentary History of the Ratification of the Constitution, edited by John P. Kaminski, Gaspare Saladino, Richard Leffler, Charles H. Schoenleber, and Margaret A. Hogan, 10:1186. Charlottesville: University of Virginia Press, [1787] 2009.

. "James Madison to Robert J. Evans." In The Writings of James Madison, edited by Gaillard Hunt, 8:439-47. New York: G. P. Putnam's Sons, [1819] 1900.

Malone, Laurence J. Opening the West: Federal Internal Improvements Before 1860. Westport, CT: Greenwood Press, 1998.

Marshall, Susan E. The New Hampshire State Constitution: A Reference Guide. Westport, CT: Greenwood Press, 2004.

Mason, George. "Debate Over the Constitution and Commentaries on the Virginia Convention, June-July 1788." In Documentary History of the Ratification of the Constitution, edited by John P. Kaminski, Gaspare Saladino, Richard Leffler, Charles H. Schoenleber, and Margaret A. Hogan, 10:1186. Charlottesville: University of Virginia Press, [1787] 2009.

McClintock, John N. History of New Hampshire. Boston: B. B. Russell, 1889.

McCurry, Stephanie. Masters of Small Worlds: Yeoman Households, Gender Relations, and the Political Culture of the Antebellum South Carolina Low Country. Oxford: Oxford University Press, 1997.

McDonnell, Michael A. "Class War? Class Struggles During the American Revolution in Virginia." William and Mary Quarterly 63, no. 2 (2006): 304-44.

McMillan, Malcolm Cook. "The Alabama Constitution of 1819: A Study of Constitution-Making on the Frontier." Alabama Lawyer 12 (1951): 74-91.

Morgan, Edmund. American Slavery, American Freedom. New York: W. W. Norton, 1975.

Nedelsky, Jennifer. Private Property and the Limits of American Constitutionalism. Chicago: Chicago University Press, 1990.

Nicholas, George. "Debate Over the Constitution and Commentaries on the Virginia Convention, June-July 1788." In Documentary History of the Ratification of the Constitution, edited by John P. Kaminski, Gaspare Saladino, Richard Leffler, Charles H. Schoenleber, and Margaret A. Hogan, 10:1341-42. Charlottesville: University of Virginia Press, [1787] 2009.

—. To the Freemen of Kentucky. Early American imprints. Series I, Evans (1639-1800). Lexington, KY: John Bradford, 1799.

Oakes, James. Freedom National: The Destruction of Slavery in the United States. New York: W. W. Norton, 2013.

Onuf, Peter S. Statehood and Union: A History of the Northwest Ordinance. Bloomington: Indiana University Press, 1987.

Orren, Karen, and Stephen Skowronek. The Search for American Political Development. Cambridge: Cambridge University Press, 2004.

Piketty, Thomas. Capital in the Twenty-First Century. Cambridge, MA: Harvard University Press, 2014.

Provine, Dorothy. Compensated Emancipation in the District of Columbia: Petitions Under the Act of April 16, 1862. Berwyn Heights, MD: Heritage Books, 2009.

Read, Jacob. "Remarks on the Floor of the U.S. Senate." In Annals of Congress in Congress of the Special Session of the Fourth Congress. Washington, DC: Gales \& Seaton, [1795] 1836.

Rice, David. Slavery Inconsistent with Justice and Good Policy. Philadelphia, PA: M. Gurney, 1792. 
Roediger, David R. Wages of Whiteness: Race and the Making of the American Working Class. London: Verso, 2007.

Salmon, Marylynn. Women and the Law of Property in Early America. Chapel Hill: University of North Carolina Press, 1989.

Sharfstein, Daniel J. "Atrocity, Entitlement, and Personhood in Property." Virginia Law Review 98, no. 3 (2012): 635-90.

Sinha, Manisha. Counterrevolution of Slavery: Politics and Ideology in Antebellum South Carolina. Chapel Hill: University of North Carolina Press, 2000.

. The Slave's Cause: A History of Abolition. New Haven, CT: Yale University Press, 2016.

Smith, Rogers M. "Beyond Tocqueville, Myrdal, and Hartz: The Multiple Traditions in America." American Political Science Review 87, no. 3 (1993): 549-66.

—. Civic Ideals: Conflicting Visions of Citizenship in U.S. History. New Haven, CT: Yale University Press, 1997.

Soltow, Lee. Distribution of Wealth and Income in the United States in 1798. Pittsburgh: University of Pittsburgh Press, 1989.

Treanor, William Michael. "The Original Understanding of the Takings Clause and the Political Process." Columbia Law Review 95, no. 4 (1995): 782-887.

Turner, Jesse. "The Constitution of 1836." Arkansas Historical Association Publications 3 (1911): 74-166.

Veazey, Thomas Ward. Annual Message of the Executive to the Legislature of Maryland, December Session 1836. Annapolis, MD: Jeremiah Hughes, 1836.

Virginia State Convention. Proceedings and Debates of the Virginia State Convention of 1829-1830. Richmond, VA: S. Shepherd, 1830.

Wilentz, Sean. The Rise of American Democracy: Jefferson to Lincoln. New York: W. W. Norton, 2005.

Winkle, John W. Mississippi State Constitution. Oxford: Oxford University Press, 2014.

Zackin, Emily. "'To Change the Fundamental Law of the State:' Protective Labor Provisions in US Constitutions." Studies in American Political Development 24, no 1 (2010): 1-23.

- Looking for Rights in All the Wrong Places: Why State Constitutions Contain America's Positive Rights. Princeton, NJ: Princeton University Press, 2013.

\section{CONSTITUTIONS AND STATUTES CITED}

Alabama Constitution of 1819 .

An Act for the Government of the Territory of the United States, South of the River Ohio, 1 Stat. 123 (1790).

An Act for the Release of Certain Persons Held to Service or Labor in the District of Columbia ("District of Columbia Compensated Emancipation Act"), 12 Stat. 376 (1862).

An Act to Accept a Cession of the Claims of the State of North Carolina to a Certain District of Western Territory, 1 Stat. 106 (1790).

An Ordinance for the Government of the Territory of the United States, Northwest of the River Ohio ("Northwest Ordinance") (1787).

Articles of Confederation (1777).

Kansas [Leavenworth] Constitution of 1858 (Failed).

Kansas [Lecompton] Constitution of 1857 (Failed).

Kentucky Constitution of 1792.

Maryland Constitution of 1776.

Maryland Declaration of Rights of 1776.

Mississippi Constitution of 1817.

New Hampshire Constitution of 1781 (Failed).

New Hampshire Constitution of 1782 (Failed).

New Hampshire Constitution of 1784. 
North Carolina Declaration of Rights of 1776.

South Carolina Constitution of 1778.

South Carolina Constitution of 1790.

US Constitution.

US Bill of Rights (1791).

Vermont Constitution of 1777.

Virginia Constitution of 1776.

Virginia Constitution of 1830.

Virginia Declaration of Rights of 1776. 